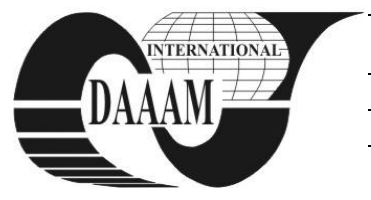

\title{
A STUDY REGARDING THE CHARACTERISTICS OF THE FLEXIBLE PLASTIC MATERIALS USED FOR BREAD PACKAGING
}

\author{
REBENCIUC, I[oana]; ALBU, E[ufrozina]; POROCH - SERITAN, M[aria] \& BUCULEI, A[melia]
}

\begin{abstract}
In this research there were tested different types of one layer and multiple layers foils used for the bread packing. The foil testing for gases permeability was done by the manometer method and the permeability determination at water vapors was done by the humidity detector method.

The foils studied presented a different permeability at gases and water vapors according to their one layer or multiple layers structure.

In the case of the evaluation of the global migration level we observed that all the studied foils presented values under the limit imposed by law and most of the values for $\mathrm{Pb}$ and $\mathrm{Cd}$ were undetectable.
\end{abstract}

Key words: permeability, polypropylene, migration, stimulant, foils, distilled water, $P P, P E$

\section{INTRODUCTION}

Considering the fact that the bakery products represent an important part of the food international market the bread industry must try to satisfy all the tendencies regarding the health diet and all the consumers requests for the fresh products. (Kotsianis, 2002).

The films usually used for bakery products packaging are usually very thin most of them being made of polypropylene (PP) and polyethylene (PE). The basic criteria in the selection of these materials are: the permeability at gas and water vapors, the sealing capacity, the thermo formation capacity, the clarity and anti fog properties. The films are fabricated either as „cast” films or as polypropylene biaxial oriented OPP films. The barrier properties of the OPP film at gases like oxygen or carbon dioxide are enhanced by the coverings in the multi-layer structures. The sealing capacity is obtained either by covering or by lamination with polyethylene or ethyl- propylene co polymers. (Crosby, 1981; Hastings, 1998; Ooraikul, 1991).

The OPP films have good barrier properties against the loss of food flavours while the coverings and multi-layer resin structures have enhanced barrier properties. The main resins used as barrier for gases are the polyvinylidene co polymers (PVDC), the acrylic co polymers and the ethylene- vinylic alcohol (EVOH) (Giles, 1999).

In this study there was analyzed the permeability at gases and water vapors things permeability having a great importance in the case of the packed bakery products. The transfer from the inner side to the outer side of the package (and vice versa) of the oxygen and water vapors is linked to the occurrence of several alterations of the product packed. The permeability of the packing foils represents the main parameter for evaluating their barrier properties in the mass transfer.

\section{MATERIALS AND METHODS}

The materials used in this study were one layer PP transparent printed foil bags (Hungarosack KFT) with a thickness of $30 \mu \mathrm{m}$ and $45 \mu \mathrm{m}$; PP laminated and printed bags with a thickness of $55 \mu \mathrm{m}$ and $75 \mu \mathrm{m}$ and multi-layer foil bags
(Hungarosack KFT) with two structures: polyamide/ polyethylene (PA/PE) and a thickness of $70 \mu \mathrm{m}$ and polyethylene terephthalate/ ethylene- vinylic alcohol /polypropylene (PET/EVOH/PP) and a thickness of $50 \mu \mathrm{m}$.

The tests for the permeability at water vapors were led with a Dansensor L80-5000 (PBI Dansensor), and the tests for the permeability at gases were led with a Dansensor L100-5000 (PBI Dansensor).

The following food stimulants were used as extraction environments in the case of studies upon the global migration of the components:simulant A (distilled water), simulant B (3\% acetic acid) $(\mathrm{m} / \mathrm{v})$ and simulant $\mathrm{C}$ (iso-octane).

The conditions for the migration test in simulant $\mathrm{A}$ (distilled water) and simulant B (3\% acetic acid) were 10 days at $40^{\circ} \mathrm{C}$, and for the simulant $\mathrm{C}$ (iso-octane) 24 hours at $40^{\circ} \mathrm{C}$.

The global migration of the components was calculated from the relation:

where:

$$
\mathrm{M}=\left(\mathrm{m}-\mathrm{m}_{1}\right) / \mathrm{V} \cdot 1000
$$

$\mathrm{M}=$ global migration, $\mathrm{mg} / \mathrm{l}$;

$\mathrm{m}=$ the mass of the substance released by the sample, $\mathrm{mg}$;

$\mathrm{m}_{1}=$ the mass of the substance released by the witness sample, $\mathrm{mg}$;

$\mathrm{V}=$ the extraction liquid evaporated volume, $\mathrm{ml}$.

The heavy metals were determined by atomic absorption spectrophotometry being used as a device the AAnalyst 600 spectrophotometer with graphite oven (PerkinElmer).

The mass of the substance released from the material submitted to research in the extraction environment was gravimetrical determined the results being expressed in $\mathrm{mg} / \mathrm{dm}^{2}$.

\section{RESULTS AND DISCUSSION}

2.1 The study regarding the analyzed foils permeability to oxygen and water vapors

The value of the permeability to oxygen for the PP foils are comparable to those indicated for the polypropylene in the scientific literature (Tareq \& Hotchkiss, 2003), the lowest permeability being found in the case of the $75 \mu \mathrm{m}$ thick foil.

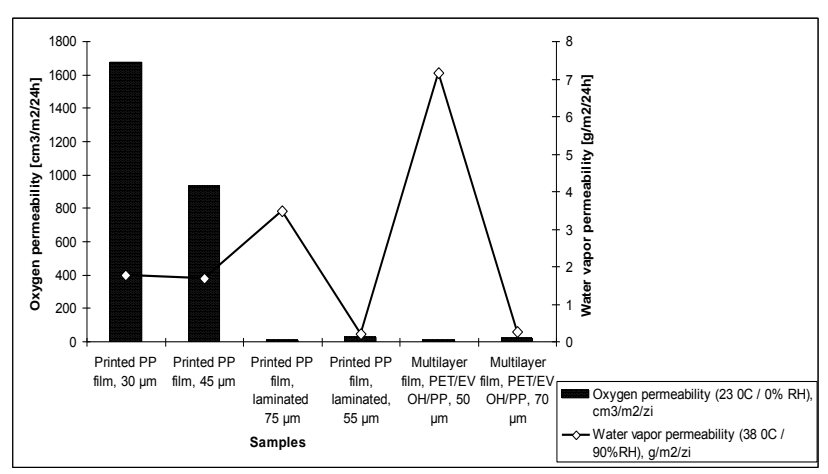

Fig. 1. The analyzed foils permeability to oxygen and water vapors 


\begin{tabular}{|c|c|c|c|c|c|c|c|}
\hline \multirow{2}{*}{ No. } & \multirow{2}{*}{ Name / Source } & \multirow{2}{*}{ Chemical nature } & \multirow{2}{*}{$\begin{array}{l}\text { Extraction } \\
\text { environemnt }\end{array}$} & \multirow{2}{*}{$\begin{array}{l}\text { Extraction } \\
\text { conditions/ } \\
\text { Extraction Raport }\end{array}$} & \multirow{2}{*}{$\begin{array}{l}\text { Global } \\
\text { migration, ppm }\end{array}$} & \multicolumn{2}{|c|}{ Metals release, ppm } \\
\hline & & & & & & $\mathbf{P b}$ & Cd \\
\hline \multirow[b]{3}{*}{1.} & \multirow{3}{*}{$\begin{array}{l}\text { PP transparent and } \\
\text { printed foil bags }\end{array}$} & \multirow[b]{3}{*}{$30 \mu \mathrm{m}$} & distilled water & 10 days, $40^{\circ} \mathrm{C} / 1: 2$ & 5,25 & - & - \\
\hline & & & acetic acid sol. & 10 days $, 40^{\circ} \mathrm{C} / 1: 2$ & 5,5 & 0,017 & $\angle \mathrm{LD}$ \\
\hline & & & iso-octane & $\begin{array}{l}48 \text { h, t.c./ } \\
1: 2\end{array}$ & 7,25 & - & - \\
\hline \multirow[b]{3}{*}{2.} & \multirow{3}{*}{ PP printed foil bags } & \multirow{3}{*}{$\begin{array}{l}\mathrm{PP} \\
45 \mu \mathrm{m}\end{array}$} & distilled water & 10 days , $40{ }^{\circ} \mathrm{C} / 1: 2$ & 5,75 & - & - \\
\hline & & & acetic acid sol. & 10 days , $40^{\circ} \mathrm{C} / 1: 2$ & 6,75 & 0,024 & $\angle \mathrm{LD}$ \\
\hline & & & iso-octane & 48 h, t.c./1:2 & 8,0 & - & - \\
\hline \multirow{3}{*}{3.} & \multirow{3}{*}{$\begin{array}{l}\text { PP laminated and } \\
\text { printed foil bags }\end{array}$} & \multirow[t]{2}{*}{$\mathrm{PP}$} & distilled water & 10 days $, 40^{\circ} \mathrm{C} / 1: 2$ & 7,0 & - & - \\
\hline & & & acetic acid sol. & 10 days $, 40^{\circ} \mathrm{C} / 1: 2$ & 16,8 & $\angle \mathrm{LD}$ & $\angle \mathrm{LD}$ \\
\hline & & $75 \mu \mathrm{m}$ & iso-octane & 48 h, t.c./1:2 & 9,5 & - & - \\
\hline \multirow{3}{*}{4.} & \multirow{3}{*}{$\begin{array}{l}\text { PP laminated and } \\
\text { printed foil bags }\end{array}$} & \multirow[t]{3}{*}{$\mathrm{PP}$} & distilled water & 10 days , $40^{\circ} \mathrm{C} / 1: 2$ & 6,5 & - & - \\
\hline & & & acetic acid sol. & 10 days , $40{ }^{\circ} \mathrm{C} / 1: 2$ & 8,5 & $<\mathrm{LD}$ & $\angle \mathrm{LD}$ \\
\hline & & & iso-octane & 48 h, t.c./1:2 & 8,0 & - & - \\
\hline \multirow{3}{*}{5.} & \multirow{3}{*}{ Multi-layer foil } & \multirow{3}{*}{$\begin{array}{l}\mathrm{PA} / \mathrm{PE} \\
70 \mu \mathrm{m}\end{array}$} & distilled water & 10 days $, 40^{\circ} \mathrm{C} / 1: 2$ & 6,5 & - & - \\
\hline & & & acetic acid sol. & 10 days , $40^{\circ} \mathrm{C} / 1: 2$ & 7,75 & $\angle \mathrm{LD}$ & $<\mathrm{LD}$ \\
\hline & & & iso-octane & 48 h, t.c. $/ 1: 2$ & 7,5 & - & - \\
\hline \multirow{3}{*}{6.} & \multirow{3}{*}{ Multi-layer foil } & \multirow[t]{3}{*}{$\mathrm{PET} / \mathrm{EVOH} / \mathrm{PP}$} & distilled water & 10 days $, 40^{\circ} \mathrm{C} / 1: 2$ & 12,9 & - & - \\
\hline & & & acetic acid sol. & 10 days $, 40^{\circ} \mathrm{C} / 1: 2$ & 28,9 & $\angle \mathrm{LD}$ & $\angle \mathrm{LD}$ \\
\hline & & & iso-octane & $\begin{array}{l}48 \mathrm{~h}, \text { t.c./ } \\
1: 2\end{array}$ & 17,3 & - & - \\
\hline
\end{tabular}

Tab. 1. The global and heavy metals $(\mathrm{Pb}, \mathrm{Cd})$ migration tests results

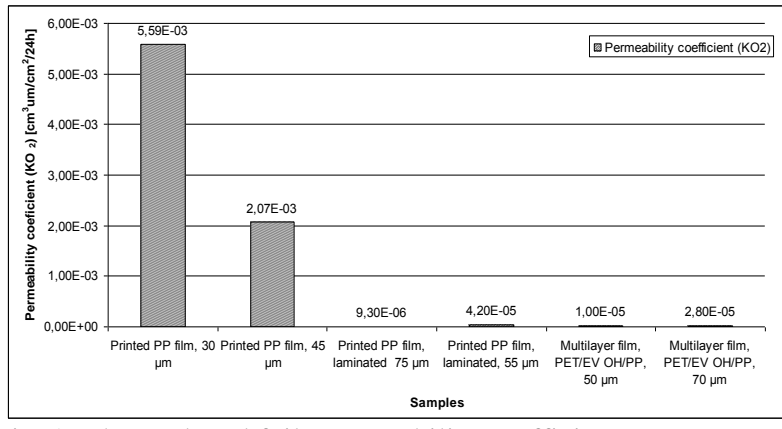

Fig. 2. The analyzed foils permeability coefficient

In the cases of the multi-layer foils PA/PE of $70 \mu \mathrm{m}$ the results for the permeability to oxygen (Figure 1) are comparable to the values indicated in the scientific literature (Tareq \& Hotchkiss, 2003).In the case of the PA (regarded as a barrier layer) sometimes the values are even lower than those obtained.The best barrier for the oxygen is attributed to the $\mathrm{PET} / \mathrm{EVOH} / \mathrm{PP}$ structure and is due to the $\mathrm{EVOH}$ layer.

The analysis of the values of permeability to water vapors indicates lower values in the cases of PP laminated and printed foil bags of $55 \mu \mathrm{m}$ and the PA/PE multi-layer foil bags of 70 $\mu \mathrm{m}$ These values indicate a good barrier property to water vapors(Figure 2).

The low values of the permeability obtained for the PP foils of $30 \mu \mathrm{m}$ and $45 \mu \mathrm{m}$ also indicate a good barrier property to water vapor $\left(<4.5 \mathrm{~g} / \mathrm{m}^{2} \cdot\right.$ day $)$.

For the multi-layer foil (PET/EVOH/PP) the water vapor permeability value is situated at an average level due to the EVOH layer.

\subsection{The study regarding the global and heavy metals} migration for the analyzed foils

Analyzing the level of global migration (table 1) we observe that all the values are situated below the limit of 10 $\mathrm{mg} / \mathrm{dm}^{2}$ (from the material surface) or $60 \mathrm{ppm}$ (free components $\mathrm{mg} / \mathrm{kg}$ of food), imposed by the regulations (90/128/EEC).

The evaluation of the results of AAS heavy metals migration analysis indicates values that are under the detection limit of the device the exceptions being made by the $\mathrm{Pb}$ in the case of one layer PP foil of $30 \mu \mathrm{m}$ and $45 \mu \mathrm{m}$.

\section{CONCLUSION}

The testing of the flexible plastic materials properties used for bakery products packing targeted the „food contact” quality testing and the barrier properties to gases and water vapors.

Considering the fact that one of the most important things for the packing of the bakery products is the "after baking"humidity transfer between the product and the environment it is recommended for the packing foil presents a average value of permeability to water vapor.

The migration of the pack components has a great importance for the "food contact" compatibility and for the hygienic quality of a pack being typical for each type of material in contact with the food product and corresponding to the mass transfer from the package into the food or from the food into the package.

In the matter of the packing materials conformity with the 90/128/EEC Directive we observed that all the global migration values correspond to the imposed limit and most of the $\mathrm{Pb}$ and $\mathrm{Cd}$ migration values were undetectable.

\section{REFERENCES}

Crosby, N.T. (1981). Food packaging requirements. In food packaging materials-aspects of analysis and migration of contaminants, London, Applied Science

A-A. Tareq and J. H. Hotchkiss (2003). The Role of Packaging Film Permselectivity in Modified Atmosphere Packaging, Journal Agric. Food Chem., 51

Hastings, M.J. (1998). In B.A. Blakistone, Principles and applications of modified atmosphere packaging of foods, Blackie Academic and Professional

Kotsianis, I.S. (2002). Production and packaging of bakery products, Trends in Food Science and Technology.

Ooraikul, B., (1991). Modified atmosphere packaging of bakery Products

***(1990) 90/128/EEC. Commission Directive of 23 February 1990 relating to plastics materials and articles intended to come into contact with foodstuffs 